\title{
SEGMENTASI PASAR PEMBELI TAHU SUMEDANG (Studi Kasus pada Perusahaan Tahu Bungkeng Kabupaten Sumedang)
}

\author{
Oleh \\ NING SRIMENGANTI \\ Universitas Winaya Mukti
}

\begin{abstract}
Abstrak
Kabupaten Sumedang dikenal sebagai daerah penghasil pangan olahan terkemuka di Jawa Barat, terkenal sebagai sentra 'tahu camilan' yang lebih dikenal dengan sebutan 'tahu Sumedang'. 'Tahu Sumedang' adalah produk lokal Kota Sumedang, yang memiliki keunikan. Keunikan tersebut misalnya dari rasanya, dari teksturnya, proses pengolahan, hingga cara penyajian dan cara memakannya. Keunikan yang khas ini ternyata hanya dimiliki di Sumedang dan menjadi faktor keunggulan tahu Sumedang dibanding tahu-tahu lainnya.Teknik yang digunakan dalam penelitian ini adalah studi kasus. Unit analisisnya adalah konsumen yang membeli tahu di Bungkeng. Objek penelitian ini adalah karakteristik pembeli yang dikelompokkan berdasarkan demografi yaitu usia, jenis kelamin, pendapatan per bulan, pekerjaan, pendidikan,agama dan domisili.Segmentasi pembeli tahu Sumedang berdasarkan hasil penelitian, yang menjadi pembeli di BUNGKENG sebagai berikut : berdasarkan rentang usia sebagian besar pembelinya berada pada rentang usia 45 - 49 tahun dengan persentase $21,68 \%$, berdasarkan jenis kelamin pembeli laki-laki lebih banyak daripada perempuan dengan persentase 50,18\%. Berdasarkan Agama, pembeli mayoritas beragama islam dengan persentase mencapai $94,18 \%$. Sedangkan dilihat dari segmen pendidikan, pendidikan terakhinya sebagian besar pembeli berpendidikan terakhir SMA dengan persentase 52,13\%. Apabila dilihat dari segmentasi pekerjaannya sebagian besar pekerja swasta dengan pendapatan $1-1,5$ juta rupiah per bulan. Segmen Demografi berdasarkan domisili menunjukan bahwa pembeli berdomisili di Jawa Barat dengan persentase $54,58 \%$.
\end{abstract}

Kata kunci: segmentasi pasar, tahu, sumedang

\section{PENDAHULUAN}

Tahu merupakan makanan yang berprotein relatif tinggi, yaitu $8-10$ persen pada tahu biasa. 11 persen pada tahu Cina dan jika dikering bekukan (dried frozen tofe) kadar proteinnya dapat mencapai 53 persen. Kadar protein tahu biasa lebih tinggi dari beras $(6-7$ persen) dan susu (3 - 4 persen). (Sutrisno Koswara, 2007).

Kebutuhan dunia akan produk hasil agroindustri cenderung semakin mengandalkan pasokan dari negara berkembang. Agroindustri merupakan suatu kegiatan yang pada saat ini seharusnya mampu mengangkat pendapatan nasional Indonesia.Potensi sumber daya Indonesia dinilai sangat melimpah sehingga pemanfaatannya harus mendapat prioritas tersendiri dalam kegiatan pembangunan. Penerapan hasil riset dan teknologi dalam pemanfaatan sumberdaya pertanian ini diharapkan mampu meningkatkan nilai tambah yang dihasilkan. Akan tetapi kesemuanya dilakukan dengan memperhatikan berbagai aspek sosial agar di satu pihak dapat menghasilkan manfaat yang sebesar-besarnya bagi kesejahteraan masyarakat dan di lain pihak menjaga keberlanjutan bagi generasi mendatang.

Nilai tambah produk pertanian bisa meningkat melalui industri pengolahan, hanya saja industri dalam konteks masa kini tidak perlu memaksakan makna produksi barang yang sama secara massal. Ketika konsumen sudah semakin demanding, industri harus bisa didesain dan menyesuaikan tuntutan customization konsumen. Industri zaman sekarang harus sanggup menyediakan beragam produk sesuai permintaan sekelompok kecil bahkan masing-masing konsumen. Pengembangan agroindustri dengan memanfaatkan bioteknologi diperhitungkan akan mampu memberikan kontribusi yang bermakna bagi upaya pemulihan krisis ekonomi sekaligus peningkatan daya saing produk agroindustri di era globalisasi yang sangat kompetitif.

Agroindustri merupakan industri secara umum yang mengandalkan SDA, teknologi, manajemen, skill yang berbasis lokal.Industri pengolahan makanan merupakan salah satu sector agroindustri yang terus berkembang saat ini. 


\section{AIMBAR \\ Agribisnis}

ISSN 2460-4321

Volume 1・Nomor 2・Januari 2016

Kabupaten Sumedang dikenal sebagai daerah penghasil pangan olahan terkemuka di Jawa Barat, terkenal sebagai sentra 'tahu camilan' yang lebih dikenal dengan sebutan 'tahu Sumedang'. 'Tahu Sumedang' adalah produk lokal Kota Sumedang, yang memiliki keunikan sehingga menjadi produk yang menasional. Keunikan tersebut misalnya dari rasanya, dari teksturnya, proses pengolahan, hingga cara penyajian dan cara memakannya. Keunikan yang khas ini ternyata hanya dimiliki di Sumedang dan menjadi faktor keunggulan tahu Sumedang dibanding tahu-tahu lainnya.

Berdasar pendahuluan tersebut maka pada perusahaan tahu Bungkeng sebagai tempat penelitian ingin diketahui bagaimana segmentasi pembeli tahu berdasarkan kriteria demografi.

\section{METODE PENELITIAN}

Penelitian ini dilaksanakan di Kelurahan Tegal Kalong,Kecamatan Sumedang Selatan Kabupaten Sumedang - Jawa Barat, tepatnya di tempat produksi dan juga penjualan Tahu Bungkeng Jl.11 April No.53. Pemilihan lokasi dilakukan secara sengaja dengan pertimbangan potensi Sumedang sebagai salah satu sentra produksi tahu. Bungkeng dipilih karena merupakan salah satu tempat pemasaran tahu Sumedang dengan skala usaha yang cukup besar dibanding yang lainnya.Teknik yang digunakan dalam penelitian ini adalah studi kasus. Menurut Husein Umar (1997), studi kasus adalah salah satu jenis metode deskriptif yang merupakan penelitian terperinci mengenai suatu objek tertentu selama kurun waktu tertentu yang cukup mendalam dan menyeluruh.

Unit analisisnya adalah konsumen yang membeli tahu di Bungkeng. Objek penelitian ini adalah karakteristik pembeli yang dikelompokkan berdasarkan demografi yaitu usia, jenis kelamin, pendapatan per bulan, pekerjaan, pendidikan,agama dan domisili. Pada penelitian ini sensus tersebut masuk dalam kategori sensus ekonomi karena digunakan untuk mengetahui segmentasi pasar konsumen.Pada penelitian ini data yang diambil adalah dengan melakukan wawancara dan pengisian kuisioner pada pembeli tahu di Bungkeng selama satu minggu berturut turut.Sensus dilakukan dari pukul 7 pagi sampai pukul 5 sore selama seminggu penuh dan tanpa adanya hari raya atau libur nasional diluar hari minggu sehingga diharapkan dapat mewakili populasi secara keseluruhan setiap harinya pada hari-hari normal.

\section{HASIL DAN PEMBAHASAN}

Segmentasi pasar pembeli tahu Sumedang ini dibagi menjadi 7 kelompok, yaitu berdasarkan Usia, Jenis Kelamin, Agama, Tingkat pendidikan, Pekerjaan, pendapatan dan Domisili. Dari keseluruhan jumlah responden penelitian yang menjadi pembeli di BUNGKENG, sebagian besar pembeli berada pada rentang usia 45 - 49 tahun $(21,68 \%)$, walaupun berbeda tipis tapi lebih banyak pembeli laki-laki $(50,84 \%)$, Pembeli mayoritas beragama Islam ( 94,18\%).Selanjutnya, berdasarkan pendidikan terakhir, maka sebagian besar pembeli berpendidikan terakhir SMA $(52,13 \%)$. Apabila dilihat dari pekerjaannya sebagian besar pekerja swasta dengan pendapatan 1-1,5 juta rupiah per bulan dan berdomisili di daerah Provinsi Jawa barat.Data lengkapnya disajikan pada tabel 9 - 15 beserta diagramnya yang menunjukkan banyaknya quota pembeli.

\section{Usia Pembeli Tahu Sumedang}

Tingkat usia mempengaruhi terhadap kegiatan berusaha, yaitu pola berfikir, keadaan fisik dan kematangan pribadi seseorang dalam bekerja dan pola konsumsi. Adapun usia pembeli tahu sumedang terlihat pada gambar dibawah ini.

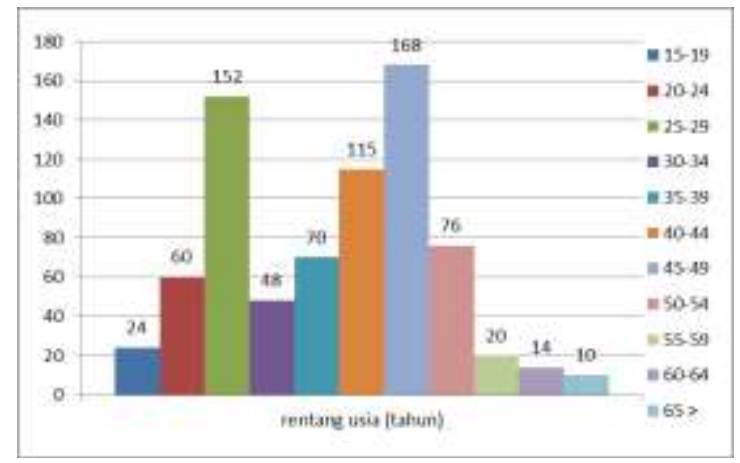

Komposisi umur pembeli secara umum menunjukkan bahwa usiapembeli dominan tergolong usia yang produktif. Pembeli terbanyak berada pada rentang usia 45 - 49 tahun dengan persentase $21,68 \%$ dan rentang usia 25 - 29 tahun dengan persentase $19,61 \%$. 
Umur 45 - 49 tahun merupakan umur individu dewasa dengan kecenderungan konsumsi terhadap kebutuhan tersier dengan harga tinggi semakin berkurang dan tuntutan beban kerja mulai menurun, serta sudah berkeluarga. Karena Tahu Sumedang merupakan makanan khas daerah Sumedang yang sudah tersohor, mereka yang bepergian dan melewati daerah Sumedang membelinya untuk oleh-oleh bagi keluarga di rumah atau bagi orang yang dikunjungi.

Yang paling sedikit adalah pembeli dengan usia 65 tahun ke atas dengan persentase 1,29\%, hal ini dikarenakan pada usia lanjut orang-orang cenderung memilih berada di rumah daripada bepergian. Kebanyakan orang pada usia lanjut hanya berperan sebagai pemakai daripada pembeli, pemakai yaitu orang yang mengkonsumsi atau menggunakan produk atau jasa yang bersangkutan sedangkan pembeli adalah orang yang melakukan pembelian yang sesungguhnya. (Kotler.2003)

Selain itu dari usia 55 tahun keatas konsumsi terhadap tahu makin sedikit, kecenderungan tersebut juga dapat dikarenakan atas pertimbangan kesehatan. Adanya kehatihatian dalam mengkonsumsi makanan saat usia beranjak tua sangat mempengaruhi pertimbangan dalam bembeli tahu karena tahu merupakan makanan dengan proses penggorengan.

\section{Jenis Kelamin Pembeli Tahu Sumedang}

Pada umumnya jenis kelamin menentukan selera dalam membeli suatu jenis barang.Dalam hal penganan tahu, dari hasil penelitian ternyata hal tersebut tidak terlalu berpengaruh.

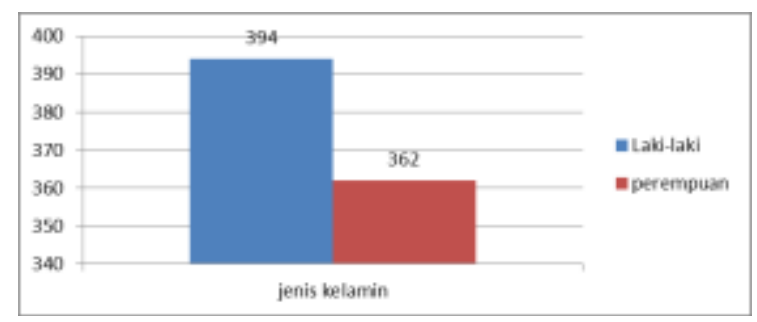

Pembeli yang lebih banyak adalah laki-laki yaitu sebanyak 394 orang dengan persentase $50,84 \%$ dan perempuan 362 orang dengan persentase $46,71 \%$. Walaupun perbedaannya tipis, tetapi dari hasil pengamatan lapangan bila jumlah responden ditambah atau waktu penelitiannya ditambah maka hasilnya akan menujukan perbedaan yang lebih signifikan bahwa pembeli laki-laki lebih banyak daripada perempuan.

Hal tersebut dikarenakan kecenderungan gender laki-laki sebagai kepala keluarga yang lebih sering membayar pada saat membeli barang sebagai bentuk tanggung jawab. Pada proses pembelian yang melibatkan satu keluarga, biasanya perempuan hanya berperan sebagai pencetus atau pemberi pengaruh,yaitu seseorang dengan pandangan atau saran yang mempengaruhi keputusan pembeli.

\section{Agama Pembeli Tahu Sumedang}

Pemilik perusahaan merupakan keturunan Cina yang sebagian keluarganya menganut agama yang minoritas di Lingkungan Sumedang. Dari hasil penelitian dapat dilihat apakah agama pemilik perusahaan berpengaruh atau tidak bagi para konsumen yang membeli tahu Sumedang,khususnya tahu Bungkeng.Hasilnya dapat terlihat pada gambar dibawah ini.

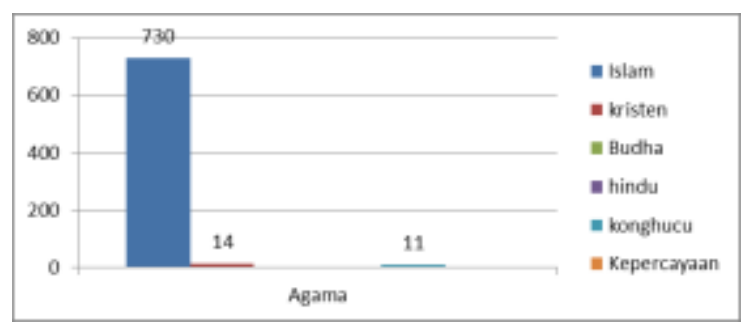

Dari gambar tersebut diketahui bahwa pembeli mayoritas adalah orang yang beragama Islam dengan persentase $94,19 \%$, lalu penganut agama Kristen bejumlah 14 orang dengan persentase $1,81 \%$, lalu konghucu 11 orang dengan persentase $1,42 \%$.Sedangkan Budha,Hindu dan kepercayaan sama sekali tidak ada. Hal tersebut membuktikan bahwa kepercayaan yang dianut tidak terlalu mempengaruhi konsumsi tahu.Penganut agama Islam lah yang paling banyak membeli karena penduduk mayoritasnya beragama Islam, jadi yang banyak terjaring sebagai pembeli secara otomatis yang menganut agama Islam.

\section{Tingkat Pendidikan Pembeli Tahu Sumedang}

Tingkat pendidikan seseorang merupakan faktor utama dalam pengetahuan, semakin tinggi tingkat pendidikan seseorang maka semakin tinggi pula pengetahuannya. Hal tersebut baik secara langsung ataupun tidak 


\section{AIMBAR \\ Agribisnis \\ ISSN 2460-4321}

Volume 1・Nomor 2・Januari 2016

langsung akan mempengaruhi dalam membuat keputusan membeli suatu barang. Untuk lebih jelasnya terlihat pada gambar dibawah ini.

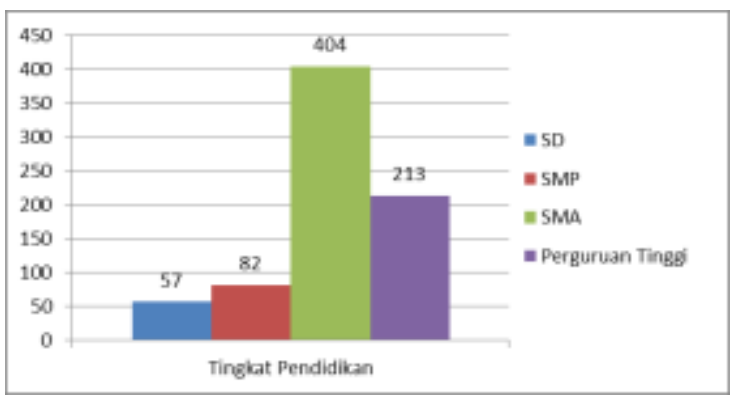

Dari data hasil penelitian diketahui bahwa hasilnya sangat beragam, tetapi pembeli yang paling banyak yaitu lulusan SMA yaitu 404 orang dengan persentase $52,13 \%$, lalu disusul oleh Lulusan perguruan tinggi sebanyak 213 orang dan SMP sebanyak 82 orang. Yang paling sedikit adalah lulusan SD yaitu 57 orang dengan persentase $7,35 \%$ yang saat ini memang sudah banyak berkurang orang-orang dengan pendidikan rendah.

Orang-orang dengan pengetahuan yang lebih tinggi cenderung membeli barang atau penganan berdasarkan kualitas dan kandungan gizi atau merk,sedangkan orang yang berpengetahuan rendah cenderung membeli barang berdasarkan kuantitas dan harga yang murah. Maka dapat dipahami bahwa para pembeli dengan tingkat pendidikan redah tidaklah banyak mengingat Bungkeng merupakan penganan dengan harga yang cukup tinggi.

\section{Pekerjaan Pembeli Tahu Sumedang}

Pekerjaan erat kaitannya dengan tingkat konsumsi. Pekerjaan dengan penghasilan tinggi akan membuat tingkat konsumsi lebih tinggi pula. Dari hasil penelitian yang dilakukan diketahui bahwa para pegawai swasta lah yang paling banyak menjadi konsumen dan yang paling sedikit adalah petani.

Saat ini perbandingan pekerjaan swasta dengan pegawai negeri jelas lebil banyak pegawai swasta, jadi secara otomatis pembeli akan lebih banyak yang pekerja sebagai swasta daripada pegawai negeri. Selain itu saat ini perusahaan Bungkeng sudah tidak melakukan kerjasama dengan instansi pemerintah daerah sebagai penyedia produk tahu untuk konsumsi pada kegiatan-kegiatan yang diadakan pemerintahan daerah Sumedang.

Hal tersebut didasarkan atas pertimbangan pemilik perusahaan yang menganggap kerjasama tersebut tidak terlalu menguntungkan bagi perusahaan. Terlalu banyak potongan harga yang diminta oleh berbagai pihak terkait yang mengakibatkan tipisnya keuntungan bagi perusahaan.

Selain itu ada juga para pembeli seperti ibu rumah tangga atau pelajar.Ibu rumah tangga dan pelajar dikategorikan sebagai orang yang tidak memiliki pekerjaan yang datanya masuk kategori "tidak terdata". Adapun data lengkapnya ada pada gambar dibawah ini.

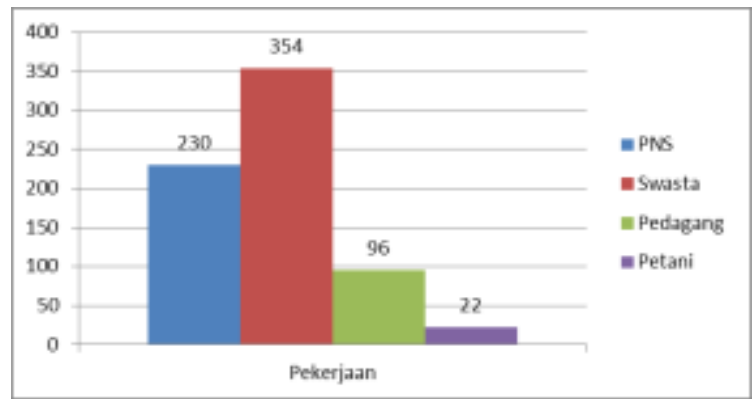

Pembeli dengan quota terbanyak adalah para pegawai swasta yaitu 354 orang dengan persentase $45,68 \%$, lalu pegawai negeri sipil yaitu sebanyak 230 orang dengan persentase $29,68 \%$, setelah itu para pedagang yang memang lokasinya dekat dengan pasar sebanyak 96orang dengan persentase 12,39\% dan yang paling sedikit adalah petani sebanyak 22 orang dengan persentase $2,84 \%$.

\section{Pendapatan Pembeli Tahu Sumedang}

Seperti halnya pekerjaan, pendapatan yang didapat dari pekerjaan tersebut sangat menentukan tingkat konsumsi dan kualitas barang yang dibeli. Konsumsi seseorang akan tegantung pada tingkat pendapatan yang telah diterima oleh seorang masyarakat (JM Keynes.1936).

Makin tinggi pendapatan seseorang maka begitu pula dengan konsumsinya.Dari hasil penelitian dapat diketahui bahwa rata-rata pembeli tahu Bungkeng berada pada tingkat menengah. Untuk lebih jelasnya dapat dilihat pada gambardibawah ini. 


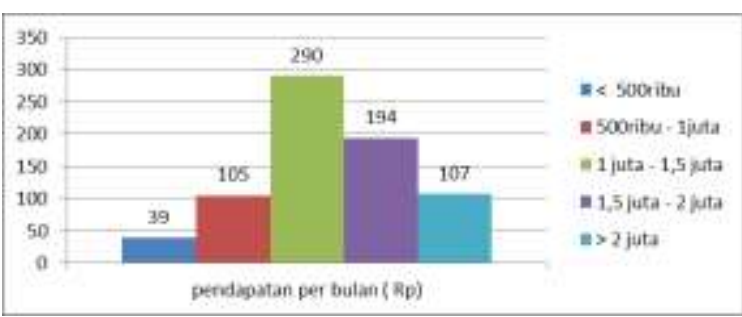

Sebagian besar responden perpendapatan 1 juta $-1,5$ juta rupiah per bulan,yaitu sebanyak 290 orang dengan persantase $37,42 \%$. Sedangkan yang paling sedikit adalah yang berpendapatan dibawah 500ribu rupiah per bulan yaitu 39 orang dengan persentase $5,03 \%$. Hal tersebut menujukkan bahwa para pembeli tahu tersebut hanya sedikit yang berpenghasilan rendah, mayoritasnya berpenghasilan sedang antara 1 juta sampai 2 juta rupiah.

\section{Domisili Pembeli Tahu Sumedang}

Dari hasil penelitian diketahui bahwa pembeli tahu Bungkeng yang paling banyak adalah orang-orang yang berdomisili di Provinsi Jawa Barat yaitu sebanyak 423 orang dengan persentase $54,58 \%$. Yang paling sedikit merupakan penduduk yang berdomisili di kabupaten Sumedang, yaitu 116 orang dengan persentase $20,77 \%$.

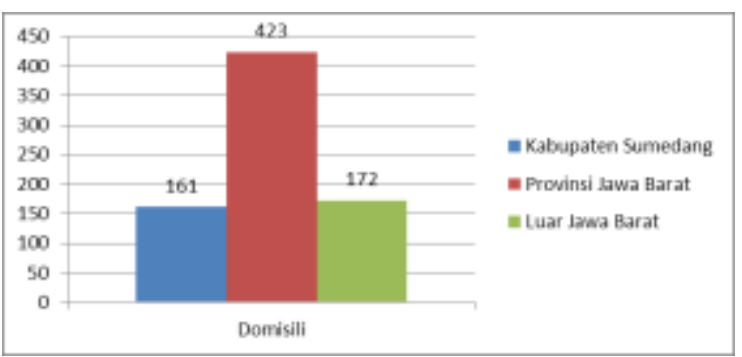

Khusus untuk outlet Bungkeng yang berada di jalan 11 April no.53 para pembelinya merupakan orang yang rata-rata sudah membeli tahu Bungkeng lebih dari satu kali.Hal tersebut karena lokasi outlet yang tidak telalu strategis lagi, jadi yang membeli di outlet jalan 11April merupakan orang-orang yang tahu lokasi perusahaan tahu Bungkeng sejak dulu. Ketika jalan Tegal Kalong (sekarang jalan 11 April) merupakan terminal, lokasi outlet bias dibilang sangat strategis karena dekat terminal dan dekat pasar.

Rata-rata pembelin yang berdomisili di Jawa Barat maupun yang di luar Jawa Barat membeli tahu sebagai oleh-oleh karena melewati kota Sumedang. Mereka memilih membeli tahu Bungkeng lebih karena Brand Loyalty daripada mencoba-coba yang lain. Bungkeng merupakan perintis tahu Sumedang dengan brandyang sudah terkenal yang kualitasnya baik.

Bagi penduduk Sumedang sendiri yang lebih banyak memiliki kesempatan untuk mencoba-coba tahu dengan brand lain banyak yang memilih brand lain sebagai alternatif pembelian.Hal tersebut selain karena harga tahu Bungkeng yang lumayan tinggi tapi juga berdasarkan selera masing - masing individu berbeda-beda terhadap rasa tahu Sumedang.

Banyak penduduk Sumedang yang berpendapat kualitas rasa tahu Bungkeng sudah menurun lalu beralih pada brand lain yang dirasa lebih baik. Makin menjamurnya perusahaan tahu di Sumedang mengakibatkan adanya banyak pilihan produk tahu yang disa dibeli di Sumedang, baik itu dari segi jenis, rasa atupun cara penjualannya. Banyak sekali para pedagang tahu asongan yang menjajakan tahunya kedalam angkutan umum, atau bahkan ke rumah-rumah sehingga para pembeli tidak lagi perlu repot-repot dating ke outlet untuk membeli tahu.Hal tersebut terlihat pada hasil penelitian yang memperlihatkan bahwa penduduk Sumedang lah yang membeli tahu Bungkeng paling sedikit.

\section{KESIMPULAN}

Berdasarkan hasil dan pembahasan dapat ditarik simpulan sebagai berikut. Segmentasi pembeli tahu Sumedang berdasarkan hasil penelitian, yang menjadi pembeli di BUNGKENG sebagai berikut : berdasarkan rentang usia sebagian besar pembelinya berada pada rentang usia 45 - 49 tahun dengan persentase $21,68 \%$,berdasarkan jenis kelamin pembeli laki-laki lebih banyak daripada perempuan dengan persentase 50,18\%. Berdasarkan Agama, pembeli mayoritas beragama islam dengan persentase mencapai $94,18 \%$. Sedangkan dilihat dari segmen pendidikan, pendidikan terakhinya sebagian besar pembeli berpendidikan terakhir SMA dengan persentase $52,13 \%$. Apabila dilihat dari segmentasi pekerjaannya sebagian besar pekerja swasta dengan pendapatan $1-1,5$ juta rupiah per bulan. Segmen Demografi berdasarkan domisili menunjukan bahwa pembeli berdomisili di Jawa Barat dengan persentase $54,58 \%$. 


\section{MIMBAR Agribisnis}

ISSN 2460-4321

Volume $1 \bullet$ Nomor $2 \cdot$ Januari 2016

\section{DAFTAR PUSTAKA}

Husein Umar. 1997. Metode Penelitian Aplikasi

Dalam Pemasaran, Gramedia Pustaka Utama, Jakarta.

Kotler ,P .2003. Manajemen Pemasaran. Jilid 1, Edisi Millenium. Prenhallindo, Jakarta.

Koswara Sutrisno. 2007. Nilai Gizi,Pengawetan dan pengolahan Tahu, Ebookpangan.com 